\title{
TGF beta signalling and its role in tumour pathogenesis ${ }^{*}$
}

\author{
Bozena Kaminska $^{\bowtie}$, Aleksandra Wesolowska and Malgorzata Danilkiewicz \\ Laboratory of Transcription Regulation, Department of Cell Biology, Nencki Institute of Experimental Biology, \\ Warszawa, Poland; ${ }_{e}$-mail: bozenakk@nencki.gov.pl
}

Received: 05 April, 2005; revised: 09 May, 2005; accepted: 31 May, 2005

available on-line: 25 June, 2005

\begin{abstract}
Transforming growth factor beta (TGF- $\beta$ ) is a multifunctional cytokine involved in the regulation of cell proliferation, differentiation and survival/or apoptosis of many cells. Knock-out experiments in mice for the three isoforms of TGF- $\beta$ have demonstrated their importance in regulating inflammation and tissue repair. TGF- $\beta$ is implicated in the pathogenesis of human diseases, including tissue fibrosis and carcinogenesis. TGF- $\beta$ receptors act through multiple intracellular pathways. Upon binding of TGF- $\beta$ with its receptor, receptor-regulated Smad2/3 proteins become phosphorylated and associate with Smad4. Such complex translocates to the nucleus, binds to DNA and regulates transcription of specific genes. Negative regulation of TGF- $\beta / S$ mad signalling may occur through the inhibitory Smad6/7. Furthermore, TGF- $\beta$-activated kinase-1 (TAK1) is a component of TGF- $\beta$ signalling and activates stress-activated kinases: p38 through MKK6 or MKK3 and c-Jun N-terminal kinases (JNKs) via MKK4. In the brain TGF- $\beta$, normally expressed at the very low level, increases dramatically after injury. Increased mRNA levels of the three TGF- $\beta$ isoforms correlate with the degree of malignancy of human gliomas. TGF- $\beta$ s are secreted as latent precursors requiring activation into the mature form. TGF- $\beta$ may contribute to tumour pathogenesis by direct support of tumour growth and influence on local microenvironment, resulting in immunosuppression, induction of angiogenesis, and modification of the extracellular matrix. TGF- $\beta 1,2$ may stimulate production of vascular endothelial growth factor (VEGF) as well as plasminogen activator inhibitor (PAI-I), that are involved in vascular remodelling occurring during angiogenesis. Blocking of TGF- $\beta$ action inhibits tumour viability, migration, metastases in mammary cancer, melanoma and prostate cancer model. Reduction of TGF- $\beta$ production and activity may be a promising target of therapeutic strategies to control tumour growth.
\end{abstract}

Keywords: TGF beta signal transduction, Smad propteins, MAP kinases, tumour invasion, cancer therapy, RNA interference.

TGF- $\beta$ is a multifunctional cytokine that regulates cell proliferation, differentiation and extracellular matrix production (Jennings \& Pietenpol, 1998; Verrecchia \& Mauviel, 2002). Deregulation of TGF$\beta$ expression or signalling has been implicated in the pathogenesis of a variety of diseases, including cancer and fibrosis. In the brain, TGF- $\beta$ is expressed at a very low level that increases dramatically after injury (Lindholm et al., 1992). Under physiological conditions TGF- $\beta$ inhibits proliferation of normal astrocytes, but loses its growth-inhibitory potential towards gliomas, due to alterations in the expression of cell cycle inhibitors. There is growing evidence that in the later stages of cancer development TGF$\beta$ is actively secreted by tumour cells and does not merely act as a bystander but rather contributes to cell growth, invasion, and metastasis and decreases host-tumour immune responses, as depicted in Fig. 1 (Jennings \& Pietenpol, 1998). The effects of distinct TGF- $\beta$ isoforms depend on the type, differentiation state and physiological conditions of target cells (Bottner et al., 2000). Despite the multitude of data regarding TGF- $\beta$ expression in different brain tumours, the molecular mechanisms underlying the expression, signalling and role of TGF- $\beta$ in pathogenesis of glioblastomas are still unknown. We summarize here data concerning molecular mechanisms of TGF- $\beta$ activation, signalling, role in tumour pathogenesis and present a rationale for evaluating TGF- $\beta$ signalling inhibitors as cancer therapeutics.

- Presented at the XXXII Winter School, 3-7 March 2005, Zakopane, Poland.

Abbreviations: ERK1/2, extracellular signal-regulated kinase 1/2; JNK, c-Jun N-terminal kinase; LAP, latency associated peptide; LTBP, latent TGF- $\beta$ binding protein; MAPK, mitogen activated protein kinase; MMP, matrix metalloproteinase; PAI-I, plasminogen activator inhibitor; shRNA, small hairpin RNA; TAK1, TGF- $\beta$-activated kinase-1; TGF- $\beta$, transforming growth factor beta; T $\beta$ RI, Type I TGF-beta receptor; T $\beta$ RII, Type II TGF-beta receptor; VEGF, vascular endothelial growth factor. 


\section{ACTIVATION OF TRANSFORMING GROWTH FACTOR $\beta$}

TGF- $\beta$ is produced and secreted in vivo as a latent complex, in which a dimer of mature growth factor is associated with the pro-peptide. The latent state prevents the cytokine from eliciting a response until certain physiological conditions occur or until the target cell is reached. TGF- $\beta$ is synthesised as 55kDa polypeptides, which dimerise shortly after production. Then the precursor molecule is cleaved in the Golgi apparatus by furine-like proteases to form small latent TGF- $\beta$ (Dubois et al., 1995). This complex contains the mature $25-\mathrm{kDa}$ protein a non-covalently bound to the N-terminal pro-peptide called LAP - latency associated peptide. Such complex may be secreted, but it usually associates with latent TGF- $\beta$ binding protein (LTBP) forming large latent TGF- $\beta$. LTBPs facilitate TGF- $\beta$ secretion and address it to the extracellular matrix. Cellular recognition of extracellular matrix-associated LTBP and subsequent recognition of latent TGF- $\beta$ are essential steps in its activation (Hyytiainen et al., 2004). The latency proteins also contribute to the cytokine stability. Free TGF- $\beta$ has a half life of about 2 min, whereas the latent form $-90 \mathrm{~min}$.
In vivo TGF- $\beta$ can be activated in an enzymatic process for example by plasmin, which concentrates at critical sites of the cell surface and is able to release mature cytokine, by cleavage of LAP (Grainger et al., 1995). Thrombospondin-1 has been reported as another protein that activates TGF- $\beta$ from small or large latent complexes and may cooperate with the plasmin-mediated process (Ribeiro et al., 1999). Further proteins participating in TGF- $\beta$ activation in vivo are: integrins, matrix metalloproteinases (MMP2 and MMP-9) and calpains. Activation of latent TGF- $\beta$ is a multi-step process and represents a regulatory stage, which translates into a tight control of active TGF- $\beta$ formation.

\section{INTRACELLULAR TGF- $\beta$ SIGNALLING PATHWAYS}

TGF- $\beta$ binds tightly to Type II receptor (T $\beta$ RII) first; this binding allows subsequent incorporation of Type I receptor (T $\beta R I)$, forming a large ligand-receptor complex involving a ligand dimer and four receptor molecules. The Type I receptor requires activation by Type II to be functional and able to bind the ligand by itself. Simultaneous binding to

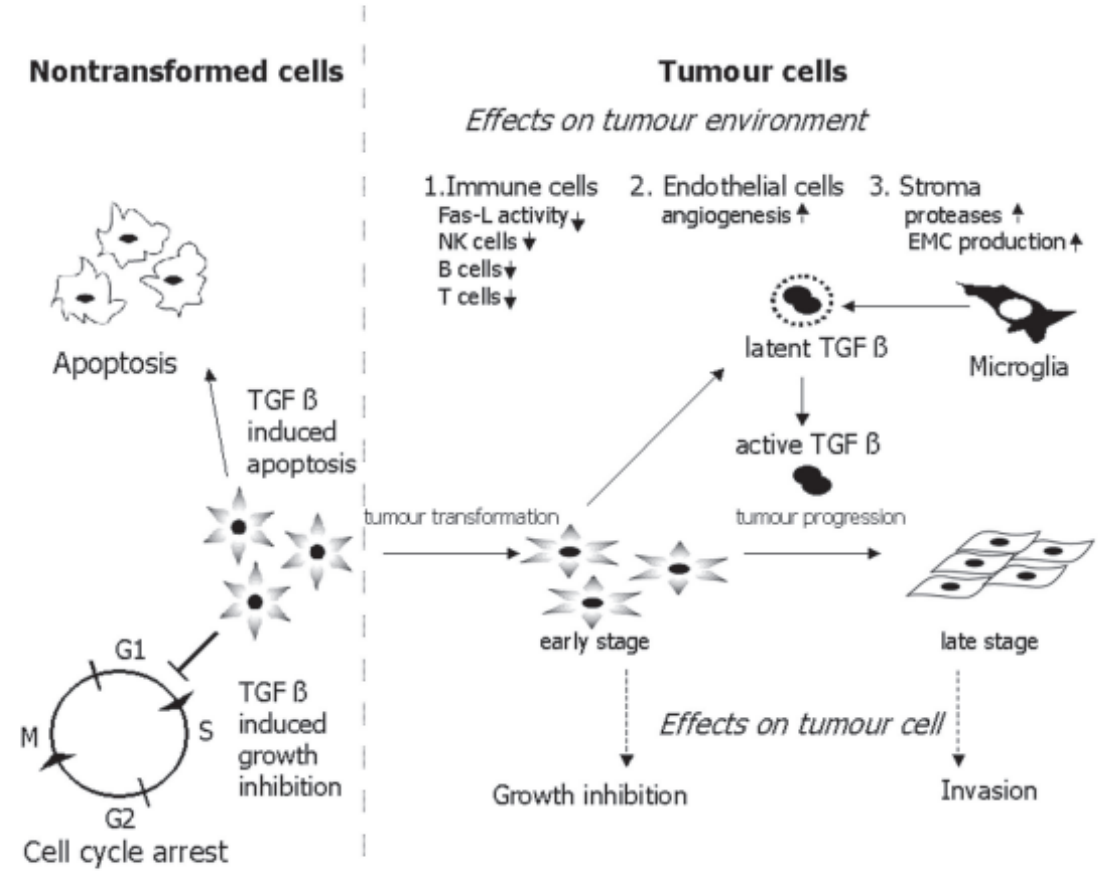

Figure 1. Possible multiple roles of TGF- $\beta$ in tumour pathogenesis.

TGF- $\beta$ can induce apoptosis or inhibit proliferation of nontransformed cells but loses its growth-inhibitory potential as cells progress to later stages of tumourigenesis. In the later stages of tumour development TGF- $\beta$ is actively secreted by tumour cells or stromal cells and contributes to cell growth, invasion, metastasis, and decrease in host anti-tumour immune responses. 
the extracellular domains of both types of the receptors by the dimeric ligand induces a close proximity and a proper conformation of the intracellular kinase domains of the receptors, facilitating the phosphorylation and subsequent activation of the Type I receptor (Shi \& Massaque, 2003). Smad proteins are basic intracellular components of TGF- $\beta$ signalling (Nakao et al., 1997b). The MH2 (MAD-homology-2) domain is highly conserved among all Smad proteins and is responsible for receptor interaction, formation of homo- and heteromeric Smad complexes, and direct contact with the nuclear pore complex for shuttling to the nucleus. Phosphorylation of the two C-terminal serine residues in the SXS motif of the MH2 domain activates the receptor Smad (Souchelnytskyi et al., 1997). After ligand binding, Smad2/3 is phosphorylated by an active form of Type I receptor (Piek et al., 1999; Attisano \& Wrana, 2002; Shi \& Massaque, 2003) and associates with the common Smad4 to form a hetero-oligomeric complex which translocates to the nucleus (Fig. 2). Following translocation, it binds to a specific DNA sequence in the promoters of target genes to regulate their transcription. The transcriptional response to TGF- $\beta$ depends also on the activity of Smad transcriptional partners. Most of the Smad partners identified to date (e.g.,
Fast1, Mixer, Jun/Fos, Runx, ATF3, E2F4/5) are highly responsive to different inputs.

The Smad signalling pathway may be negatively regulated by the inhibitory Smad6 and Smad7 (Nakao et al., 1997a). Inhibitory Smad7 acts to oppose the signal mediated by Smads by forming stable associations with activated Type I receptors, thus preventing phosphorylation of receptor Smads and acting as a negative feedback regulator (Shi \& Massaque, 2003). Moreover, transcriptionally activated by TGF- $\beta$ signaling, Smad7 promotes the ubiquitination and degradation of the receptors via Smurf1/2 proteins. Smad6 competes with Smad1 for binding to Smad4 (Massague \& Wotton, 2000; Derynck \& Zhang, 2003).

Although the Smad pathway is widely represented in most of the cell types studied, additional pathways may be activated following treatment with TGF- $\beta$ in specific contexts (Fig. 2). For example, activation of Ras, extracellular signal-regulated kinase 1/2 (ERK1/2), and c-Jun N-terminal kinase (JNK) by TGF- $\beta$ signalling have been reported in primary intestinal epithelial cells and some breast cancer cell lines (for a review see Mulder et al., 2000), whereas activation of protein kinase A contributes to TGF$\beta$ signalling in murine mesangial cells (Wang et al.,

\section{TGFß signalling pathways}

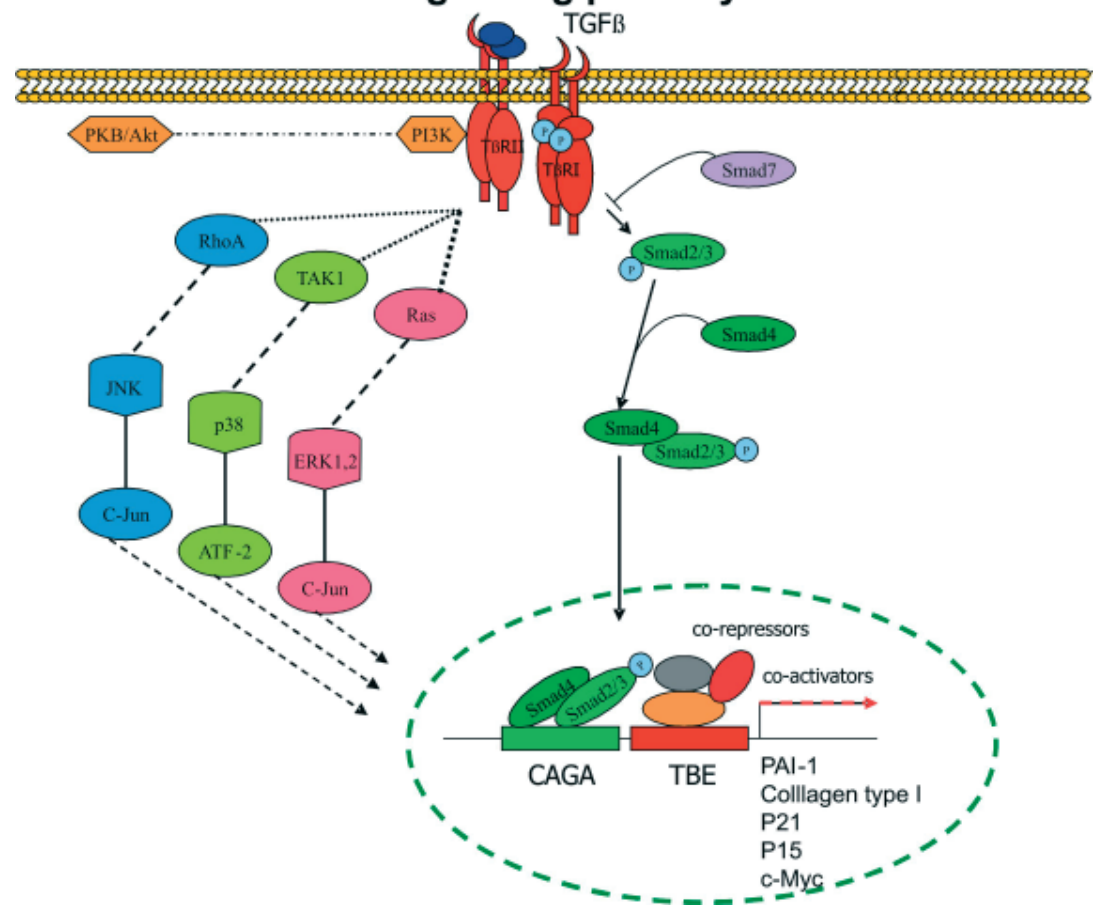

Figure 2. TGF- $\beta$ signalling pathways.

TGF- $\beta$ dimer binds to Type II receptors which leads to association with Type I receptors, conformational changes and activation of kinase domains of the receptors. Smad 2/3 proteins are cytoplasmic molecules which, after receptor activation, are phosphorylated by an active form of Type I receptor and associates with Smad 4. Hetero-oligomeric complex of Smad 2/3-Smad4 translocates to the nucleus and binds to specific DNA sequence in the promoters of target genes. The pathway is regulated by the activity of the inhibitory Smad7. TGF- $\beta$ can activate several mitogen activated protein kinases (MAPKs), including extracellular signal-regulated kinases (ERKs), c-Jun N-terminal kinases (JNKs), and p38 MAPK. The interaction with these MAP kinases could regulate Smad transcriptional activity in a positive or a negative manner. 
1998). TGF- $\beta$ activated kinase-1 (TAK1), a member of the MEKK family and activator of JNK and p38 MAPK pathways (Yamaguchi et al., 1995), was rapidly activated by TGF- $\beta$. Selective activation of p38 MAPK, with no apparent activation of JNK after TGF- $\beta$ stimulation was reported for C2C12, Mv1Lu, and HaCaT cells (Hanafusa et al., 1999; Karsdal et al., 2003).

Recent studies suggest that different signalling modules may be responsible for a unique functions of the cytokine in epithelial cells. MEK, an inducer of Erk, appeared to be a major mediator of TGF- $\beta 1$ dependent PAI-1 expression and cell motility in renal epithelial cells (Kutz et al., 2001). TGF- $\beta$ activates the Ras/MKK4/JNK1 signalling cascade, leading to induction of AP-1 activity, which, in turn, up-regulates UPAR (receptor of urokinase-type plasminogen activator) expression in nontransformed intestinal epithelial cells. Type II TGF- $\beta$ receptor is required for activation of JNK1 and the resulting up-regulation of UPAR expression (Yue et al., 2004). In mouse mammary epithelial cells, activation of p38 MAPK is required for TGF- $\beta$-induced apoptosis, epithelialto-mesenchymal transition, but not growth arrest (Ungefroren et al., 2003; Yoo et al., 2003). TGF- $\beta 1$ signalling potentiates staurosporine-induced apoptosis of renal epithelial cells by a Smad-independent, p38 MAP kinase-dependent mechanism (Dai et al., 2003). In transformed human epidermal keratinocytes, TGF- $\beta$ activates differently various MAPKs (Johansson et al., 2000). p38 MAPK mediates TGF- $\beta$-induced expression of MMP-2 and MMP-9 in MCF10A human breast epithelial cells (Kim et al., 2004).

\section{REGULATION OF TGF- $\beta$ EXPRESSION IN TUMOUR CELLS}

The promoter regions of genes encoding three mammalian transforming growth factors- $\beta$ (TGF- $\beta 1$, $2,3)$ show little similarity in sequence, indicating differential transcriptional regulation of the genes, whose protein products are functionally very similar. Inspection of the TGF- $\beta 1$ and TGF- $\beta 3$ promoters reveals the presence of several putative regulatory elements, including several Sp1 and AP-1 transcription factor binding sites. Promoter fragments of the TGF- $\beta 1$ and TGF- $\beta 3$ genes, but not of TGF- $\beta 2$, were able to compete for binding of Sp1 to DNA oligomers containing consensus Sp1-binding sites (Geiser et al., 1993).

An important property of TGF- $\beta 1$ is an ability to activate its mRNA expression and thereby its own secretion (Van Obberghen-Schilling et al., 1988; Kim et al., 1990; Jennings et al., 1991; Jachimczak et al., 1996). The crucial role of the AP-1 transcription factor in the autocrine regulation of TGF- $\beta 1$ expression has been demonstrated in human lymphoma cells and adenocarcinoma A-549 cells (BirchenallRoberts et al., 1990; Kim et al., 1990). The authors identified three AP-1-binding elements responsible for the auto-induction. Antisense $c$-jun and antisense $c$-fos blocked autocrine TGF- $\beta 1$-induced expression, confirming an involvement of these two components in the mechanism. This property of TGF- $\beta 1$ may underlie the observed autocrine growth regulatory effect of the cytokine in glioma cells (Jennings et al., 1991). Contribution of c-Jun N-terminal kinase (JNK) signalling to the control of TGF- $\beta$ expression has been proposed after observing that JNK-deficient fibroblasts isolated from Jnk1-/- Jnk2-/- mice constitutively express TGF- $\beta 1$. Complementation studies demonstrated that JNK is a repressor of TGF- $\beta 1$ gene expression (Ventura et al., 2004).

Some studies demonstrated that Cyclosporine A (CsA) induces increased expression of TGF- $\beta$ in vitro as well as in vivo. CsA stimulated TGF- $\beta 1$ promoter-dependent transcription of CAT reporter gene in transiently transfected human A-549 cells as well as the synthesis of TGF- $\beta$ mRNA in human T cells (Prashar et al., 1995). Hojo et al. (1999) reported that CsA enhances the TGF $\beta$ production in A-549 adenocarcinoma cells that correlated with acquisition of a more aggressive phenotype and their enhanced invasiveness. Glucocorticoid dexamethasone causes a significant decrease in the basal and PMA-induced levels of TGF- $\beta 1$ mRNA in glial cells but not in T cells (Batuman et al., 1995).

Also post-transcriptional regulation of TGF$\beta 1$ expression has been reported in A-549 and PC3 human prostate adenocarcinoma cells (Kim et al., 1992). An increased level of the protein released to the culture medium does not always correlate with increased mRNA level of TGF- $\beta 1$. It has been suggested that the $5^{\prime}$ untranslated region (UTR) of TGF$\beta 1$ mRNA containing a stem-loop element may contribute to enhanced mRNA stability.

\section{ROLE OF TGF- $\beta$ IN TUMOUR PATHOGENESIS}

\section{Alterations of TGF- $\beta$ signalling pathways contribute to tumour risk}

There is growing evidence that alterations in TGF- $\beta$ signalling pathway components modify cancer risk. Approximately $14 \%$ of the general population carry TGFBR1*6A, a variant of the TGFBR1 gene that results in decreased TGF- $\beta$-mediated growth inhibition. Recent studies show that the overall cancer risk is increased by 70 and $19 \%$ among TGFBR $1^{*} 6 \mathrm{~A}$ homozygotes and heterozygotes, respectively (Kaklamani et al., 2003). This suggests that TGFBR1*6A may contribute to the development of a large proportion of common forms of cancer and may become a target for cancer chemoprevention. 
Mutational inactivation of TGFBR2 is the most common genetic event affecting the TGF- $\beta$ signalling pathway and occurs in approx. $20-30 \%$ of all colon cancers (Biswas et al., 2004). Using a mouse model that is null for Tgfbr2 in the colonic epithelium (Cre-lox inactivation of TGFIIR), the authors demonstrated that a loss of TGFBIIR expression in colon epithelial cells promotes the establishment and progression of azoxymethane-induced colon neoplasms, suggesting that TGFBR2 is a tumour suppressor gene in the colon. While decreased TGF- $\beta$ signalling increases cancer risk, TGF- $\beta$ secretion and activated TGF- $\beta$ signalling enhance the aggressiveness of several types of tumours.

\section{Role of TGF- $\beta$ in tumour migration}

The invasion of neoplastic cells into brain tissue is a pathologic hallmark of gliomas and contributes to the failure of current therapeutic modalities (surgery, radiation and chemotherapy). Glioma cells have the ability to invade as single cells through the unique environment of the normal central nervous system (CNS). The brain parenchyma has a unique composition, mainly hyaluronan and is devoid of rigid protein barriers composed of collagen, fibronectin and laminin. Proteases secreted during glioma progression degrade extracellular matrix allowing tumour cells to spread and diffusely infiltrate the brain parenchyma (Rao, 2003).

Exogenous TGF- $\beta 1$ directly increases the motility of glioma cells by enhancing expression of collagen and subunit of $\alpha_{2,5}, \beta_{3}$ integrin, as well as by up-regulating the activity of metalloproteinases MMP-2, 9 at the cell surface of glioma cells (Wick et al., 2001). Interaction between cell surface receptors such as integrins, and extracellular matrix components, for instance collagen, is essential for tumour metastasis and angiogenesis (Verrecchia \& Mauviel, 2002). Additionally, increased enzymatic degradation of extracellular matrix proteins may facilitate tumour spread (Platten et al., 2001; Wick et al., 2001).

\section{TGF- $\beta 1$ as pro-angiogenic factor}

Moreover, TGF- $\beta 1$ may act as an angiogenic factor promoting neovascularization of the tumour. TGF- $\beta 1,2$ stimulate production of vascular endothelial growth factor (VEGF), which is a major stimulus in the promotion of angiogenesis, as well as plasminogen activator inhibitor (PAI-I) (Benckert et al., 2003; Sugano et al., 2003). Both are involved in vascular remodelling which occurs during angiogenesis (Kaur et al., 2004). TGF- $\beta 1$ stimulates VEGF 164 via mitogen-activated protein kinase kinase 3 (MKK3) and activation of p38 $\alpha$ and p388 MAPK-dependent pathway in murine mesangial cells (Wang et al., 2004). Some studies demonstrated that hy- poxia and TGF- $\beta$ signalling pathways can synergize in the regulation of VEGF gene expression at the transcriptional level and cooperate in the induction of the promoter activity of VEGF. This cooperation has been mapped on the human VEGF promoter within a region at -1006 to -954 that contains functional DNA-binding sequences for HIF-1 and Smads (Sanchez-Elsner et al., 2001).

\section{Role of TGF- $\beta$ in tumour-mediated immunosuppres- sion}

TGF- $\beta$ plays a crucial role in the escape of glioma from host immunity. The anti-tumour response in patients with glioma may be ineffective because of a lack of a specific tumour antigen and professional antigen presenting cells in the brain. TGF- $\beta 1$ enhances this effect by inhibition of MHC class II expression on glioma cells, macrophages and microglia (Lee et al., 1997; Dong et al., 2001; Zagzag et al., 2005). TGF- $\beta 1$ exerts an immunosuppressive effect on all cells of the immune system (Jachimczak et al., 1993; Beck et al., 2001; Chen et al., 2005). The main target of its action are $\mathrm{T}$ lymphocytes, which could develop into effector $\left(\mathrm{CD} 8^{+} \mathrm{CTL}\right)$ or helper $\left(\mathrm{CD} 4^{+} \mathrm{Th} 1\right.$ or Th2) cells. Although several cytokines have been reported to influence differentiation of naive $\mathrm{T}$ cells, TGF- $\beta 1$ is the most effective inhibitor of their maturation. In the presence of this cytokine, $\mathrm{CD} 8^{+}$failed to come CTL and $\mathrm{CD}^{+}$did not achieve the Th1 or Th2 phenotype (Gorelik \& Flavell, 2001). Th2 differentiation seems to be more sensitive to this effect. There is evidence, that TGF- $\beta 1$ inhibits generation of cytotoxic $\mathrm{CD}^{+} \mathrm{T}$ cell subpopulation, although the mechanism has not been clarified. TGF- $\beta 1$ suppresses granzyme B and perforin expression that are crucial for the cytolytic action of cytotoxic lymphocytes (Smyth et al., 1991).

There are contradictory results concerning the anti-proliferative effect of TGF- $\beta 1$ on CTL (Inge et al., 1992). Under some experimental conditions the effect induced by TGF- $\beta 1$ was due to suppression of such immunostimulatory cytokine expression as INF $\gamma$ and TNF $\alpha$ or down-regulation of IL-2-mediated proliferative signals (Ranges et al., 1987). TGF$\beta 1$ can also abolish $\mathrm{T}$ cell activation by a negative effect on antigen presenting cells, such as dendritic cells. TGF- $\beta 1$ can also suppress macrophages by down-regulation of $\mathrm{TNF} \alpha, \mathrm{H}_{2} \mathrm{O}_{2}$ and $\mathrm{NO}$ production. Moreover, TGF- $\beta 1$ enhances the production of immunosuppressive IL-10 by macrophages (Maeda et al., 1995). Additional targets of TGF- $\beta 1$-mediated immunosuppression are natural killer (NK) and lymphokine activated killer cells (LAK), as well as neutrophils (Kuppner et al., 1988).

Blocking of TGF- $\beta 1$ signalling in the immune system cells led to enhanced anti-tumour response. Both thymoma and melanoma-derived cell lines 
were eradicated by animals expressing a dominant negative T $\beta$ RII under the control of a T-specific promoter (Gorelik \& Flavell, 2001). In addition, CTLs transduced with a vector expressing dominant negative T $\beta$ RII were resistant to the anti-proliferative and anti-cytotoxic effects of exogenous TGF- $\beta 1$ in EBVpositive Hodgkin disease (Bollard et al., 2002). Taken together, efforts to bypass TGF- $\beta$-mediated immunosuppression represent an attractive therapeutic strategy for the treatment of human cancers, both by directly increasing the efficacy of immunosurveillance and the efficacy of tumour immunotherapy.

\section{DEVELOPMENT OF INHIBITORS OF TGF- $\beta$ SIGNALLING}

The TGF- $\beta$ signalling pathway is emerging as an attractive target in cancer and it is predicted that inhibitors of this pathway will find their way into cancer clinical trials, leading to delays in tumour progression and improvement in overall survival. Blockade of TGF- $\beta$ action inhibited mammary tumour cell viability, migration, and metastases (Muraoka et al., 2002). Introduction of dominant negative TGF- $\beta$ Type II receptors (T $\beta$ RII) into these cells retards primary tumour and metastases formation and prevents epithelial-to-mesenchymal transition (EMT) (Oft et al., 1998). Retrovirus-mediated introduction of a dominant negative TGFIIR to bone marrow cells led to generation of leukocytes capable of potent anti-tumour response and suppression of metastasis in melanoma and prostate cancer model (Shah et al., 2002). The tumorigenicity of mouse thymoma was suppressed by soluble - TGFIIR therapy (Won et al., 1999).

Table 1 summarizes recent therapeutic approaches targeting the TGF- $\beta$ pathway. One strategy is based on blocking the interactions between the cytokine and its receptor. For example, an application of soluble TGFIIR or human $\alpha 2$-macroglobulin plasma protein that bind TGF- $\beta$ isoform, limited the access of the cytokine to the receptor (Won et al., 1999). Two humanized monoclonal antibodies: CAT192 specific to TGF- $\beta 1$ and CAT-152 against TGF- $\beta 2$, are under clinical trial for treatment of fibrosis (Benigni et al., 2003; Mead et al., 2003). Positive results of these investigations will encourage application of this strategy to anti-cancer therapy.

The antisense oligonuclotide approach is represented by the AP-12009 molecule blocking TGF- $\beta 2$ expression in tumour cells (Bogdahn et al., 2004). Data obtained from phase I/II studies indicated a significant increase in survival time of glioblastoma patients that correlated with the reduction of tumour size by more than $80 \%$. Additionally, a TGF- $\beta 1-$ specific antisense oligonuclotide (AP-11014) designed by the same company, Antisense Pharma, is under preclinical development for human non-small cell lung carcinoma, colorectal and prostate cancer. Recently, an effective strategy based on RNA interference was used to reduce TGF- $\beta$ activity in malignant cells. Blockade of cytokine expression using siRNA against TGF- $\beta$ inhibited tumour cell migration, invasiveness and restored anti-tumour immune response in a mouse model of glioma (Friese et al., 2004). We have applied a similar strategy and developed vectors coding for small hairpin RNA which silence TGF- $\beta$ receptor Type II gene expression by RNA interference in human glioblastoma cells. Transfection of glioblastoma cells with these vectors effectively diminished the expression of TGF $\beta$ II receptor, abolished TGF-activated Smad signalling and reduced activation of the PAI-1 promoter (Wesolowska et al., unpublished).

Another approach is aimed at directly blocking the catalytic activity of TGF receptor kinase. A group of competitive inhibitors of the ATP binding

Table 1. Development of inhibitors of TGF- $\beta$ signalling

\begin{tabular}{|c|c|c|c|c|}
\hline Agent & Type & Development stages & Company & References \\
\hline $\begin{array}{l}\text { Lerdelimumb } \\
\text { CAT-152 }\end{array}$ & TGF- $\beta 2 \mathrm{mAb}$ & Phase III & $\begin{array}{l}\text { Cambridge } \\
\text { Antibody Technology }\end{array}$ & Mead et al., 2003 \\
\hline $\begin{array}{l}\text { Metelimumab } \\
\text { CAT-192 }\end{array}$ & TGF- $\beta 1 \mathrm{mAb}$ & Phase II & $\begin{array}{l}\text { Cambridge } \\
\text { Antibody Technology }\end{array}$ & Benigni et al., 2003 \\
\hline AP-12009 & $\begin{array}{l}\text { Oligonucleotide } \\
\text { anti TGF- } \beta 2\end{array}$ & Phase II & $\begin{array}{l}\text { Antisense } \\
\text { Pharma }\end{array}$ & Bogdahn et al., 2004 \\
\hline AP-11014 & $\begin{array}{l}\text { Oligonucleotide } \\
\text { anti TGF- } \beta 2\end{array}$ & Preclinical & $\begin{array}{l}\text { Antisense } \\
\text { Pharma }\end{array}$ & $\begin{array}{l}\text { Schlingensiepen et al., } \\
2004\end{array}$ \\
\hline $\begin{array}{l}\text { LY550410 } \\
\text { LY580276 }\end{array}$ & $\begin{array}{l}\text { Small molecule } \\
\mathrm{T} \beta \mathrm{RI} \text { inhibitor }\end{array}$ & Preclinical & Lilly Research & Sawyer et al., 2004 \\
\hline SB505124 & $\begin{array}{l}\text { Small molecule } \\
\mathrm{T} \beta \mathrm{RI} \text { inhibitor }\end{array}$ & Preclinical & GlaxoSmithKline & $\begin{array}{l}\text { DaCosta Byfield et al., } \\
2004\end{array}$ \\
\hline SB-431542 & $\begin{array}{l}\text { Small molecule } \\
\mathrm{T} \beta \mathrm{RI} \text { inhibitor }\end{array}$ & Preclinical & GlaxoSmithKline & Hjelmeland et al., 2004 \\
\hline SD-208 & $\begin{array}{l}\text { Small molecule } \\
\mathrm{T} \beta \text { RI inhibitor }\end{array}$ & Preclinical & Academic Institution & Uhl et al., 2004 \\
\hline
\end{tabular}


site of TGF receptor Type I kinase, such as LY550410, LY580276 and SB-505124, has been designed. Such compounds consist of domain with a hydrogenbond acceptor (which may be imidazole core, pyrozole ring or quinoline scaffold) essential for blocking. Several studies demonstrated physiological efficacy of such molecules, as well as their kinase inhibitory activity (Sawyer et al., 2004; DaCosta Byfield et al., 2004). Another small-molecule inhibitor SD-208 appears to be a very potent antagonist of TGF- $\beta$ receptor. The drug significantly prolonged the survival time of glioma-bearing mice. In the presence of the inhibitor, the immunogenicity of glioma cells was enhanced, while their migratory and invasion properties were diminished (Uhl et al., 2004).

Moreover, small-molecule inhibitors (such as SB-431542) have been developed that target downstream TGF- $\beta$ signalling and block phosphorylation of Smad proteins, resulting in the inhibition of Smad nuclear translocation. TGF- $\beta$-mediated up-regulation of critical genes was abolished in human glioma cells by a treatment with SB-431542 (Inman et al., 2001; Hjelmeland et al., 2003). However, such an approach will not affect Smad-independent pathways.

A large-molecule antagonist of TGF- $\beta$ signalling seems to be more selective and may have broader action than small-molecule inhibitors. Despite earlier predictions of severe toxicity, neutralizing antibodies to TGF- $\beta$ are well tolerated and have potent anti-metastatic activity. Si/shRNAs are recognized as a new class of potential therapeutics against a wide range of diseases. Recent data obtained in several laboratories demonstrate the efficacy of systemically administered shRNA as a therapeutic strategy in experimental cancers. However, the success of this approach will largely depend on efficient delivery of shRNAs to tumour cells. Transfection of shRNA with lentiviral or adeno-associated vectors in cultured mammalian cells and in whole animals may be a promising approach in specific, efficient, and stable knockdown of various genes (An et al., 2003; Tiscornia et al., 2003; Grimm et al., 2005).

\section{Acknowledgements}

The work in the Author's Laboratory is supported by grant No. PBZ-MIN-107-/P04/2004 from the Ministry of Science Research and Information Technology.

A.W. is a recipient of a scholarship from Postgraduate School of Molecular Medicine. M.D. is a recipient of a scholarship from Foundation for Polish Science.

\section{REFERENCES}

An DS, Xie Y, Mao SH, Morizono K, Kung SK, Chen IS (2003) Efficient lentiviral vectors for short hairpin RNA delivery into human cells. Hum Gene Ther 14: 12071212.

Attisano L, Wrana JL (2002) Signal transduction by TGF- $\beta$ superfamily. Science 296: 1646-1647.

Batuman OA, Ferrero A, Cupp C, Jimenez SA, Khalili K (1995) Differential regulation of transforming growth factor $\beta$-1 gene expression by glucocorticoids in human $\mathrm{T}$ and glial cells. J Immunol 155: 4397-4405.

Beck C, Schreiber H, Rowley D (2001) Role of TGF- $\beta$ in immune-evasion of cancer. Microsc Res Tech 52: 387-395.

Benckert C, Jonas S, Cramer T, Von Marschall Z, Schafer G, Peters M, Wagner K, Radke C, Wiedenmann B, Neuhaus P, Hocker M, Rosewicz S (2003) Transforming growth factor $\beta 1$ stimulates vascular endothelial growth factor gene transcription in human cholangiocellular carcinoma cells. Cancer Res 63: 1083-1092.

Benigni A, Zoja C, Corna D, Zatelli C, Conti S, Campana M, Gagliardini E, Rottoli D, Zanchi C, Abbate M, Ledbetter S, Remuzzi G (2003) Add-on anti-TGF- $\beta$ antibody to ACE inhibitor arrests progressive diabetic nephropathy in the rat. J Am Soc Nephrol 14: 1816-1824.

Birchenall-Roberts MC, Ruscetti FW, Kasper J, Lee HD, Friedman R, Geiser A, Sporn MB, Roberts AB, Kim SJ (1990) Transcriptional regulation of the transforming growth factor $\beta 1$ promoter by $\mathrm{v}$-src gene products is mediated through the AP-1 complex. Mol Cell Biol 10: 4978-4983.

Biswas S, Chytil A, Washington K, Romero-Gallo J, Gorska AE, Wirth PS, Gautam S, Moses HL, Grady WM (2004) Transforming growth factor $\beta$ receptor Type II inactivation promotes the establishment and progression of colon cancer. Cancer Res 64: 4687-4692.

Bogdahn U, Hau P, Brawanski A, Schlaier J, Mehdorn M, Wurm G, Pichler J, Kunst M, Stauder G, Schlingensiepen KH (2004) Specific therapy for high-grade glioma by convection-enhanced delivery of the TGF$\beta 2$ specific antisense oligonucleotide AP 12009. Am Soc Clin Oncol Ann Meet. Abstract 1514.

Bollard CM, Rossig C, Calonge MJ, Huls MH, Wagner HJ, Massague J, Brenner MK, Heslop HE, Rooney CM (2002) Adapting of transforming growth factor $\beta$ - related tumor protection strategy to enhance antitumor immunity. Blood 99: 3179-3187.

Bottner M, Krieglstein K, Unsicker K (2000) The transforming growth factor- $\beta \mathrm{s}$ : structure, signaling, and roles in nervous system development and functions. J Neurochem 75: 2227-2240.

Chen ML, Pittet MJ, Gorelik L, Flavell RA, Weissleder R, von Boehmer H, Khazaie K (2005) Regulatory $\mathrm{T}$ cells suppress tumor-specific CD8 T cell cytotoxicity through TGF- $\beta$ signals in vivo. Proc Natl Acad Sci USA 102: 419-424.

Dai C, Yang J, Liu Y (2003) Transforming growth factor$\beta 1$ potentiates renal tubular epithelial cell death by a mechanism independent of Smad signaling, J Biol Chem 278: 12537-12545.

DaCosta Byfield S, Major C, Laping NJ, Roberts AB (2004) SB-505124 is a selective inhibitor of transforming growth factor $\beta$ type I receptors ALK4, ALK5 and ALK7. Mol Pharmacol 65: 744-752.

Derynck R, Zhang YE (2003) Smad-dependent and Smadindependent pathways in TGF- $\beta$ family signalling. $\mathrm{Na}$ ture 425: 577-584.

Dong Y, Tang L, Letterio JJ, Benveniste EN (2001) The Smad3 protein is involved in TGF- $\beta$ inhibition of class II transactivator and class II MHC expression. J Immunol 167: 311-319.

Dubois CM, Laprise MH, Blanchette F, Gentry LE, Leduc $R$ (1995) Processing of transforming growth factor $\beta 1$ 
precursor by human furin convertase. J Biol Chem 270: 10618-10624.

Friese MA, Wischhusen J, Wick W, Weiler M, Eisele G, Steinle A, Weller M (2004) RNA interference targeting transforming growth factor $\beta$ enhances NKG2D-mediated antiglioma immune response, inhibits glioma cell migration and invasiveness and abrogates tumorigenicity in vivo. Cancer Res 64: 7596-7603.

Geiser AG, Busam KJ, Kim SJ, Lafyatis R, O'Reilly MA, Webbink R, Roberts AB, Sporn MB (1993) Regulation of the transforming growth factor- $\beta 1$ and $-\beta 3$ promoters by transcription factor Sp1. Gene 129: 223-228.

Gorelik L, Flavell RA (2001) Immune-mediated eradication of tumors through the blockade of transforming growth factor $\beta$. Nat Med 7: 1118-1122.

Grainger DJ, Wakefield L, Bethell HW, Farndale RW, Metcalfe JC (1995) Release and activation of platelet latent TGF- $\beta$ in blood clots during dissolution with plasmin. Nat Med 1: 932-937.

Grimm D, Pandey K, Kay MA (2005) Adeno-associated virus vectors for short hairpin RNA expression. Methods Enzymol 392: 381-405.

Hanafusa H, Ninomiya-Tsuji J, Masuyama N, Nishita M, Fujisawa J, Shibuya H, Matsumoto K, Nishida E (1999) Involvement of the p38 mitogen-activated protein kinase pathway in transforming growth factor- $\beta$-induced gene expression. J Biol Chem 274: 27161-27167.

Hjelmeland MD, Hjelmeland AB, Sathornsumetee S, Reese ED, Herbstreith MH, Laping NJ, Friedman HS, Bigner DD, Wang XF, Rich JN (2003) SB-431542, a small molecule transforming growth factor- $\beta$. receptor antagonist, inhibits human glioma cell line proliferation and motility. Mol Cancer Ther 3: 737-745.

Hojo M, Morimoto T, Maluccio M, Asano T, Morimoto K, Lagman M, Shimbo T, Suthanthiran M (1999) Cyclosporine induces cancer progression by a cell-autonomous mechanism. Nature 6719: 530-534.

Hyytiainen M, Penttinen C, Keski-Oja J (2004) Latent TGF$\beta$ binding proteins: extracellular matrix association and roles in TGF- $\beta$ activation. Crit Rev Clin Lab Sci 41: 233-264.

Inge TH, Hoover SK, Susskind BM, Barrett SK, Bear HD (1992) Inhibition of tumor-specific cytotoxic T-lymphocyte responses by transforming growth factor $\beta 1$. Cancer Res 52: 1386-1392.

Inman GJ, Nicolas FJ, Callahan JF, Harling JD, Gaster LM, Reith AD, Laping NJ, Hill CS (2001) SB-431542 is a potent and specific inhibitor of transforming growth factor $\beta$ superfamily Type I activin receptor-like kinase (ALK) receptors ALK4, ALK5 and ALK7. Mol Pharmacol 62: 65-74.

Jachimczak P, Bogdahn U, Schneider J, Behl C, Meixensberger J, Apfel R, Dorries R, Schlingensiepen KH, Brysch W (1993) The effect of transforming growth factor$\beta$ 2-specific phosphorothioate-anti-sense oligodeoxynucleotides in reversing cellular immunosuppression in malignant glioma. I Neurosurg 78: 944-951.

Jachimczak P, Hessdorfer B, Fabel-Schulte K, Wismeth C, Brysch W, Schlingensiepen $\mathrm{KH}$, Bauer A, Blesch A, Bogdahn U (1996) Transforming growth factor- $\beta$-mediated autocrine growth regulation of gliomas as detected with phosphorothioate antisense oligonucleotides. Int J Cancer 65: 332-337.

Jennings MT, Pietenpol JA (1998) The role of transforming growth factor $\beta$ in glioma progression. J Neurooncol 36: 123-140.

Jennings MT, Maciunas RJ, Carver R, Bascom CC, Juneau P, Misulis K, Moses HL (1991) TGF $\beta 1$ and TGF $\beta 2$ are potential growth regulators for low-grade and ma- lignant gliomas in vitro: evidence in support of an autocrine hypothesis. Int J Cancer 49: 129-139.

Johansson N, Ala-aho R, Uitto V, Grenman R, Fusenig NE, Lopez-Otin C, Kahari VM (2000) Expression of collagenase-3 (MMP-13) and collagenase-1 (MMP-1) by transformed keratinocytes is dependent on the activity of p38 mitogen-activated protein kinase. J Cell Sci 113: 227-235.

Kaklamani VG, Hou N, Bian Y, Reich J, Offit K, Michel LS, Rubinstein WS, Rademaker A, Pasche B (2003) TGF $\beta R 1^{*} 6 \mathrm{~A}$ and cancer risk: a meta-analysis of seven case-control studies. J Clin Oncol 21: 3236-3243.

Karsdal MA, Hjorth P, Henriksen K, Kirkegaard T, Nielsen KL, Lou H, Delaisse JM, Foged NT (2003) Transforming growth factor- $\beta$ controls human osteoclastogenesis through the p38 MAPK and regulation of RANK expression. J Biol Chem 278: 44975-44987.

Kaur B, Tan C, Brat DJ, Post DE, Van Meir EG (2004) Genetic and hypoxic regulation of angiogenesis in gliomas. I Neurooncol 70: 229-243.

Kim SJ, Angel P, Lafyatis R, Hattori K, Kim KY, Sporn MB, Karin M, Roberts AB (1990) Autoinduction of transforming growth factor $\beta 1$ is mediated by the AP1 complex. Mol Cell Biol 10: 1492-1497.

Kim SJ, Park K, Koeller D, Kim KY, Wakefield LM, Sporn MB, Roberts AB (1992) Post-transcriptional regulation of the human transforming growth factor- $\beta 1$ gene. $J$ Biol Chem 267: 13702-13707.

Kim ES, Kim MS, Moon A (2004) TGF- $\beta$-induced upregulation of MMP-2 and MMP-9 depends on p38 MAPK, but not ERK signaling in MCF10A human breast epithelial cells. Int J Oncol 25: 1375-1382.

Kuppner MC, Hamou MF, Bodmer S, Fontana A, de Tribolet N (1988) The glioblastoma-derived T-cell suppressor factor/ transforming growth factor $\beta 2$ inhibits the generation of lymphokine-activated killer (LAK) cells. Int J Cancer 4: 562-567.

Kutz SM, Hordines J, McKeown-Longo PJ, Higgins PJ (2001) TGF- 31 -induced PAI-1 gene expression requires MEK activity and cell-to-substrate adhesion. J Cell Sci 114: 3905-3914.

Lee YJ, Han Y, Lu HT, Nguyen V, Qin H, Howe PH, Hocevar BA, Boss JM, Ransohoff RM, Benveniste EN (1997) TGF- $\beta$ suppresses IFN-gamma induction of class II MHC gene expression by inhibiting class II transactivator messenger RNA expression. J. Immunol 158: 2065-2075.

Lindholm D, Castren E, Kiefer R, Zafra F, Thoenen H (1992) Transforming growth factor- $\beta 1$ in the rat brain: increase after injury and inhibition of astrocyte proliferation. J Cell Biol 117: 395-400.

Massague J, Wotton D (2000) Transcriptional control by the TGF $3 /$ Smad signaling system. EMBO J 19: 1745-1754.

Maeda H, Kuwahara H, Ichimura Y, Ohtsuki M, Kurakata S, Shiraishi A (1995) TGF- $\beta$ enhances macrophage ability to produce IL-10 in normal and tumor-bearing mice. I Immunol 155: 4926-4932.

Mead AL, Wong TT, Cordeiro MF, Anderson IK, Khaw PT (2003) Evaluation of anti-TGF- $\beta 2$ antibody as a new postoperative anti-scarring agent in glaucoma surgery. Invest Ophthalmol Vis Sci 44: 3394-3401

Mulder KM (2000) Role of Ras and Mapks in TGF $\beta$ signaling. Cytokine Growth Factor Rev 11: 23-35.

Muraoka RS, Dumont N, Ritter CA, Dugger TC, Brantley DM, Chen J, Easterly E, Roebuck LR, Ryan S, Gotwals PJ, Koteliansky V, Arteaga CL (2002) Blockade of TGF$\beta$ inhibits mammary tumor cell viability, migration, and metastases. J Clin Invest 109: 1551-1559.

Nakao A, Afrakhte M, Moren A, Nakayama T, Christian JL, Heuchel R, Itoh S, Kawabata M, Heldin NE, Hel- 
din CH, Ten Dijke P (1997) Identification of Smad7, a TGF $\beta$-inducible antagonist of TGF- $\beta$ signalling. Nature 389: 631-635.

Nakao A, Imamura T, Souchelnytskyi S, Kawabata M, Ishisaki A, Oeda E, Tamaki $\mathrm{K}$, Hanai J, Heldin $\mathrm{CH}$, Miyazono K, Ten Dijke P (1997) TGF- $\beta$ receptor-mediated signalling through Smad2, Smad3 and Smad4. EMBO J 16: $5353-5362$

Oft M, Heider KH, Beug H (1998) TGF $\beta$ signaling is necessary for carcinoma cell invasiveness and metastasis. Curr Biol 8: 1243-1252.

Platten M, Wick W, Weller M (2001) Malignant glioma biology: role for TGF- $\beta$ in growth, motility, angiogenesis, and immune escape. Microsc Res Tech 52: 401-410.

Piek E, Heldin CH, Ten Dijke P (1999) Specificity, diversity, and regulation in TGF- $\beta$ superfamily signaling. FASEB J 13: 2105-2124.

Prashar Y, Khanna A, Sehajpal P, Sharma VK, Suthanthiran M (1995) Stimulation of transforming growth factor- $\beta 1$ transcription by cyclosporine. FEBS Lett 358: 109-112.

Ranges GE, Figari IS, Espevik T, Palladino MA Jr (1987) Inhibition of cytotoxic $\mathrm{T}$ cell development by transforming growth factor $\beta$ and reversal by recombinant tumor necrosis factor $\alpha$. J Exp Med 166: 991-998.

Rao JS (2003) Molecular mechanisms of glioma invasiveness: the role of proteases. Nat Rev Cancer 3: 489-501.

Ribeiro SM, Poczatek M, Schultz-Cherry S, Villain M, Murphy-Ullrich JE (1999) The activation sequence of thrombospondin-1 interacts with the latency-associated peptide to regulate activation of latent transforming growth factor- $\beta$. J Biol Chem 274: 13586-13593.

Sanchez-Elsner T, Botella LM, Velasco B, Corbi A, Attisano L, Bernabeu C ( 2001) Synergistic cooperation between hypoxia and transforming growth factor- $\beta$ pathways on human vascular endothelial growth factor gene expression. J Biol Chem 276: 38527-38535.

Sawyer JS, Beight DW, Britt KS, Anderson BD, Campbell RM, Goodson T Jr, Herron DK, Li HY, McMillen WT, Mort N, Parsons S, Smith EC, Wagner JR, Yan L, Zhang F, Yingling JM (2004) Synthesis and activity of new aryl- and heteroaryl-substituted 5,6-dihydro-4Hpyrrollo[1,2-b]pyrozole inhibitors of the transforming growth factor $\beta$ type I receptor kinase domain. BioMed Chem Lett 14: 3581-3584.

Schlingensiepen $\mathrm{KH}$, Bischof A, Egger T, Hafner M, Herrmuth $\mathrm{H}$, Jachimczak P, Kielmanowicz M, Niewel M, Zavadova E, Stauder G (2004) The TGF- $\beta 1$ antisense oligonucleotide AP 11014 for the treatment of non-small cell lung, colorectal and prostate cancer: Preclinical studies. Am Soc Clin Oncol Ann Meeting Abstract 3132.

Shah AH, Tabayoyong WB, Kundu SD, Kim SJ, Van Parijs L, Liu VC, Kwon E, Greenberg NM, Lee C (2002) Suppression of tumor metastasis by blockade of transforming growth factor $\beta$ signaling in bone marrow cells through a retroviral-mediated gene therapy in mice. Cancer Res 62: 7135-7138.

Shi Y, Massague J (2003) Mechanisms of TGF- $\beta$ signaling from cell membrane to the nucleus. Cell 113: 685-700.

Smyth MJ, Strobl SL, Young HA, Ortaldo JR, Ochoa AC (1991) Regulation of lymphokine-activated killer activity and pore-forming protein gene expression in human peripheral blood CD8+ T lymphocytes. Inhibition by transforming growth factor $\beta$. J Immunol 146: 3289-3297.

Souchelnytskyi S, Tamaki K, Engstrom U, Wernstedt C, Ten Dijke P, Heldin CH (1997) Phosphorylation of Ser465 and Ser467 in the $C$ terminus of Smad2 mediates interaction with Smad4 and is required for transforming growth factor- $\beta$ signalling. J Biol Chem 272: 28107-28115.
Sugano Y, Matsuzaki K, Tahashi Y, Furukawa F, Mori S, Yamagata H, Yoshida K, Matsushita M, Nishizawa M, Fujisawa J, Inoue K (2003) Distortion of autocrine transforming growth factor $\beta$ signal accelerates malignant potential by enhancing cell growth as well as PAI-1 and VEGF production in human hepatocellular carcinoma cells. Oncogene 22: 2309-2321.

Tiscornia G, Singer O, Ikawa M, Verma IM (2003) A general method for gene knockdown in mice by using lentiviral vectors expressing small interfering RNA. Proc Natl Acad Sci USA 100: 1844-1848.

Uhl M, Aulwurm S, Wischhusen J, Weiler M, Ma JY, Almirez R, Mangadu R, Liu YW, Platten M, Herrlinger U, Murphy A, Wong DH, Wick W, Higgins LS, Weller M (2004) SD-208, a novel of transforming growth factor $\beta$ receptor kinase inhibitor, inhibits growth and invasiveness and enhances immunogenicity of murine and human glioma cells in vitro and in vivo. Cancer Res 64: 7954-7961.

Ungefroren $\mathrm{H}$, Lenschow $\mathrm{W}$, Chen $\mathrm{WB}$, Faendrich $\mathrm{F}$, Kalthoff H (2003) Regulation of biglycan gene expression by transforming growth factor- $\beta$ requires MKK6-p38 mitogen-activated protein kinase signaling downstream of Smad signaling. J Biol Chem 278: 1104111049.

Van Obberghen-Schilling E, Roche NS, Flanders KC, Sporn MB, Roberts AB (1988) Transforming growth factor $\beta 1$ positively regulates its own expression in normal and transformed cells. J Biol Chem 263: 7741-7746.

Ventura JJ, Kennedy NJ, Flavell RA, Davis RJ (2004) JNK regulates autocrine expression of TGF- $\beta 1$. Mol Cell 15: 269-278.

Wang L, Zhu Y, Sharma K (1998) Transforming growth factor- $\beta 1$ stimulates protein kinase $\mathrm{A}$ in mesangial cells. J Biol Chem 273: 8522-8527.

Wang L, Kwak JH, Kim SI, He Y, Choi ME (2004) Transforming growth factor- $\beta 1$ stimulates vascular endothelial growth factor 164 via mitogen-activated protein kinase kinase 3-p38 $\alpha$ and p38 mitogen-activated protein kinase-dependent pathway in murine mesangial cells. J Biol Chem 279: 33213-33219.

Wick W, Platten M, Weller M (2001) Glioma cell invasion: regulation of metalloproteinase activity by TGF- $\beta$. Neurooncol 53: 177-185.

Won J, Kim H, Park EJ, Hong Y, Kim SJ, Yun Y (1999) Tumorigenicity of mouse thymoma is suppressed by soluble Type II transforming growth factor $\beta$ receptor therapy. Cancer Res 59: 1273-1277.

Yamaguchi K, Shirakabe K, Shibuya H, Irie K, Oishi I, Ueno N, Taniguchi T, Nishida E, Matsumoto K (1995) Identification of a member of the MAPKKK family as a potential mediator of TGF- $\beta$ signal transduction. Science 270: 2008-2011.

Yoo Y, Ghiassi M, Jirmanova L, Balliet AG, Hoffman B, Fornace AJ Jr, Liebermann DA, Bottinger EP, Roberts AB (2003) Transforming growth factor- $\beta$-induced apoptosis is mediated by Smad-dependent expression of GADD45b through p38 activation. J Biol Chem 278: 43001-43007.

Yue J, Sun B, Liu G, Mulder KM (2004) Requirement of TGF- $\beta$ receptor-dependent activation of c-Jun N-terminal kinases (JNKs)/stress-activated protein kinases (Sapks) for TGF- $\beta$ up-regulation of the urokinase-type plasminogen activator receptor. J Cell Physiol 199: 284292.

Zagzag D, Salnikow K, Chiriboga L, Yee H, Lan L, Ali MA, Garcia R, Demaria S, Newcomb EW (2005) Downregulation of major histocompatibility complex antigens in invading glioma cells: stealth invasion of the brain. Lab Invest 85: 328-341. 